\title{
The Effect Of Advertising, Sales Promotion, And Brand Image On Repurchasing Intention (Study On Shopee Users)
}

Muchsin S. Shihab ${ }^{1}$, Maulida Azmi ${ }^{2}$, Indra ${ }^{3}$, Muhamad Zahruddin ${ }^{4}$, Diana Putri Lazirkha ${ }^{5}$ Faculty of Economics and Business ${ }^{1,2}$, Faculty of Information System ${ }^{3,4,5}$

Bakrie University 1,2

University of Raharja ${ }^{3,4,5}$

Kawasan Rasuna Epicentrum, Jl. H. R. Rasuna Said No.2, RT.2/RW.5, Karet, Kecamatan

Setiabudi, Kuningan, Daerah Khusus Ibukota Jakarta $12940^{1,2}$

JI. Jenderal Sudirman No.40, RT.002/RW.006, Cikokol, Kec. Tangerang, Kota Tangerang,

Banten $15117^{3,4,5}$

Indonesia

e-mail: muchsin.shihab@bakrie.ac.id ${ }^{1}$, admisi@bakrie.ac.id² ${ }^{2}$ indra.indra@raharia.info ${ }^{3}$, $\underline{\text { zahruddin@raharia.info }}^{4}$, diana.putri@raharia.info ${ }^{5}$

To cite this document:

S. Shihab, M., Azmi, M., Indra, Zahruddin, M., \& Lazirkha, D. P. (2021). The Effect Of Advertising, Sales Promotion, And Brand Image On Repurchasing Intention (Study On Shopee Users). IAIC Transactions on Sustainable Digital Innovation (ITSDI), 3(2), 76-85. Retrieved from https://aptikom-journal.id/index.php/itsdi/article/view/527

DOI: https://doi.org/10.34306/itsdi.v3i2.527

\begin{abstract}
The background of this research comes from the current trend of online shopping as nowadays online shopping is often used by consumers. One of the top brands in e-commerce is Shopee, although Shopee have many visitors, but it does not reflect the high repurchase intention that can be seen from the value of the Shopee transaction. Therefore, it is important for companies to know the factors that influence the repurchase intention from Shopee. The purpose of this study is to find out the factors that affect repurchase intention in consumers using Shopee applications through advertisements, sales promotions, and brand image. This type of research is quantitative research. The data presented in this study were obtained through a questionnaire given to 110 respondents. Statistical analysis using SPSS 16 is used in the model and hypothesis testing. The results of this study indicate that advertising, sales promotion, and brand image have a positive effect on repurchase intention in Shopee.
\end{abstract}

Keywords: Repurchase Intention, Advertising, Sales Promotion, Brand Image

\section{Introduction}

The higher the business opportunity in the e-commerce industry, the more competitive the level [1]. Based on E-commerce Map data released by iprice.co.id,Shopee managed to maintain its first position as the top e-commerce ten consecutive quarters from the first quarter of 2017 to the second quarter of 2019 based on rankings on PlayStore. In the second quarter of 2019, Shopee also led the AppStore ranking category. 


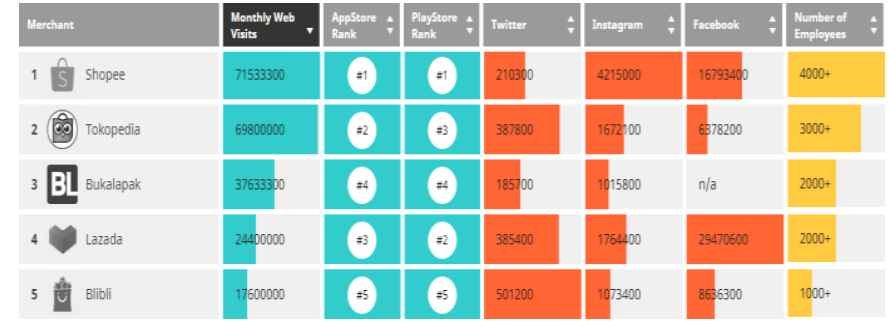

Figure 1. Quartal Web Visit 12020

Therefore it is important to know what factors can affect the buying interest of consumers. Researchers had conducted an initial pre-survey using a temporary questionnaire distributed to 20 respondents. The results of the initial survey conducted online shown in Table 1 are as follows:

Table 1.1 Questions, Answers and Percentages of Early Surveys

\begin{tabular}{|c|c|c|c|}
\hline Question & Answer & Score & Percentage \\
\hline \multirow{3}{*}{$\begin{array}{l}\text { What factors are } \\
\text { your consideration } \\
\text { to return to using } \\
\text { the Shopee } \\
\text { application as a } \\
\text { place to shop } \\
\text { online? }\end{array}$} & $\begin{array}{l}\text { 1. Advertising } \\
\text { (Attractive ads, high ad exposure on social } \\
\text { media) }\end{array}$ & 7 & $35 \%$ \\
\hline & $\begin{array}{l}\text { 2. Sales Promotion } \\
\text { (voucher, free postage, } \\
\text { flash sale, attractive price, harbolnas) }\end{array}$ & 17 & $85 \%$ \\
\hline & $\begin{array}{l}\text { 3. Brand Image } \\
\text { (Brand Preferences, friend/family references, } \\
\text { interesting, fun, reliable, value app features) }\end{array}$ & 10 & $50 \%$ \\
\hline
\end{tabular}

\section{Research Method}

This research is a type of quantitative research that can be used to examine populations and samples that are generally done randomly or randomly. Then this research aims to test previous theories with predetermined research variables [2].

The data retrieval techniques in this study use primary data collection methods and secondary data:

\section{Primary Data}

Primary data collection is done through surveys using questionnaires shared with respondents [3]. The questionnaire will be distributed online with the help of google forms.

\section{Secondary Data}

Secondary data collection on this study through references from several documents. The secondary data used in this study has a relationship with, advertising, sales promotion, brand image and buying interest sourced from several research journals, books, articles, both in the form of hardcopy and softcopy [4].

\subsection{Formula/Algorithm}

To determine the number of samples using the slovin method with a $10 \%$ fault tolerance [5]. So that it can be formulated as follows:

$$
\mathrm{n}=\frac{N}{1+N e^{2}}
$$


Information:

$\mathrm{n}$ : Large sample

$\mathrm{N}$ : Large population

e: great deviation (error) that is : $10 \%(0,1)$

Out of a total of $10,000,000$ population, it was obtained :

$$
\begin{aligned}
\mathrm{n} & =\frac{10000000}{1+10000000^{*} 0.1^{2}} \\
& =\frac{10000000}{100000} \\
& =100
\end{aligned}
$$

From the formulation, the number of samples was 100 respondents, added $10 \%$ so that the number of final samples used was as many as 110 respondents.

\subsection{Literature Review}

The following table contains some of the previous studies, related to this study..

Table 2 Previous Research

\begin{tabular}{|c|l|l|l|}
\hline No & \multicolumn{1}{|c|}{$\begin{array}{c}\text { Name of } \\
\text { researcher }\end{array}$} & \multicolumn{1}{|c|}{ Variable Research } & \multicolumn{1}{c|}{ Research Results } \\
\hline 1 & $\begin{array}{l}\text { (Prabowo \& } \\
\text { [6] }\end{array}$ & $\begin{array}{l}\text { Service quality, brand } \\
\text { image, and word of } \\
\text { mouth on repurchase } \\
\text { intention. }\end{array}$ & $\begin{array}{l}\text { Service quality, brand image, and word } \\
\text { of mouth have an impact on } \\
\text { repurchaseintention directly and } \\
\text { indirectly }\end{array}$ \\
\hline 2. & $\begin{array}{l}\text { (Raji dkk, } \\
\text { 2019) [7] }\end{array}$ & $\begin{array}{l}\text { Social media } \\
\text { advertising content, } \\
\text { social media sales } \\
\text { promotion content, } \\
\text { hedonic brand image, } \\
\text { functional brand } \\
\text { image and behavioural } \\
\text { intention }\end{array}$ & $\begin{array}{l}\text { Hedonic and functional brand images } \\
\text { have a significant mediating effect on } \\
\text { social media advertising content, social } \\
\text { media sales promotion content, and } \\
\text { behavioral intentions.. }\end{array}$ \\
\hline 3. & $\begin{array}{l}\text { and } \\
\text { 2019) [8] [9] }\end{array}$ & $\begin{array}{l}\text { Promotion, Corporate } \\
\text { image,service } \\
\text { quality,Customer } \\
\text { satisfaction, Repeat } \\
\text { purchase }\end{array}$ & $\begin{array}{l}\text { There is a positive influence on promo- } \\
\text { company image, service and } \\
\text { customer satisfaction with Repurchase } \\
\text { intention }\end{array}$ \\
\hline
\end{tabular}




\begin{tabular}{|l|l|l|l|}
\hline 4. & (Seber,V.2019) \\
{$[10]$} & $\begin{array}{l}\text { Interaction Via Social } \\
\text { Media; Past Online } \\
\text { Shopping Experience; } \\
\text { Repurchase Intention; } \\
\text { Trust }\end{array}$ & $\begin{array}{l}\text { Interactions on social media and } \\
\text { previous online shopping experiences } \\
\text { have had a significant influence on } \\
\text { buying interest through trust. }\end{array}$ \\
\hline 5. & $\begin{array}{l}\text { (Sitinjak,T. } \\
\text { 2019) [11] }\end{array}$ & $\begin{array}{l}\text { Advertising, Sales } \\
\text { Promotion, Perceived } \\
\text { Ease of Use, Reuse } \\
\text { Intention }\end{array}$ & $\begin{array}{l}\text { Iklan, promosi penjualan, dan persepsi } \\
\text { kemudahan penggunaan berpengaruh } \\
\text { positif terhadap repurchase intention }\end{array}$ \\
\hline
\end{tabular}

2.3 Hypotheses

\section{Ads, Re-buy interests}

Active advertising on social media platforms can provide consumers with accurate information about a company's brand [11] which proves that advertising has a positive effect on interest in re-using GO-PAY services in Jakarta. So that the first hypothesis can be summarized by:

H1. Social media ads are positively associated with buy-back interest

\section{Sales Promotion, Re-buy interest}

The better the sales promotion is done, the higher the service users and means the interest in re-wearing the creation is also higher [12] [13]. Likewise, research conducted by Ndubisi and Moi proved that there is an influence of sales promotion on re-buying interest through trials and also research conducted by Sitinjak Tony [11] that proves sales promotion has a positive impact on buy-to-let interest. So that the second hypothesis can be formulated by:

H2. Sales promotions have a positive effect on buy-back interest

\section{Brand Image, Re-Buy interest}

Soleha in his research revealed there is a positive influence and also the sigifikan of brand image on buy-to-let interest [14]. Sari and Santika also revealed that brand image variables have a positive and significant effect on buy-to-re-interest [15]. With the good image of a brand that is perceived both by consumers, can encourage the higher the desire or intention of consumers to get back in touch or transact which in this case is to repurchase the brand. In addition, Prabowo \& Respati [6], also found that brand image influences buying interest. Based on the results of the study, the third hypothesis is formulated by:

H3: Brand Image positively affects buying interest

\section{Advertising, Sales Promotion and Brand Image, Re-buy interest}

H4: Advertising, Sales promotion, Brand Image together have a positive effect on re-buying interest

\section{Findings}

\section{Advertising, Sales Promotion, Brand Image Shopee}

\section{A. Advertisement}

Ads on Shopee can be one of the factors that may affect the buying interest of Shopee itself [16]. Based on Shopee's latest ad, namely with brand ambassador Didi Kempot who promotes 2.2 Men Sale discount. 


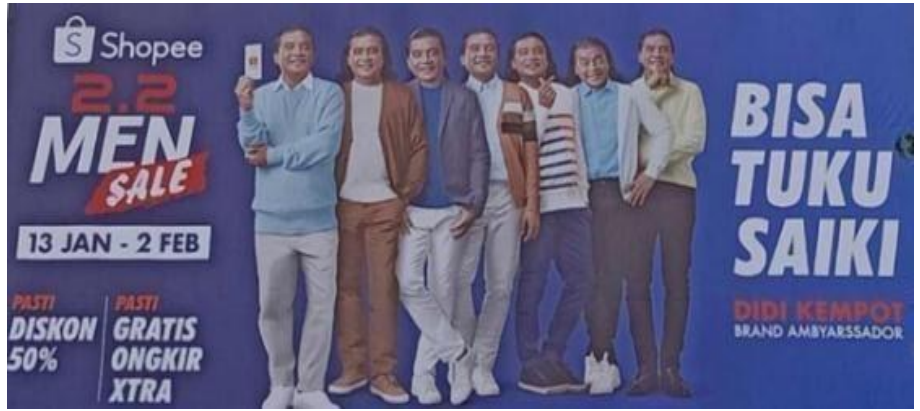

Figure 2. Shopee Advertisement Brand Ambassador Didi Kempot

Based on the ads from the brand ambassador didit kempot, this ad is quite interesting to visit and quite persuasive. Thus it can be concluded that Shopee ads already serve to communicate customer value persuasively so as to create the use and interest in re-buying a service [17] [18]. Shopee ads can be said to be quite successful in the actions of buyers, who have met the criteria of AIDA Attention (containing attractiveness), Interest (containing attention and interest), Desire (giving rise to the desire to try), Action (leading to action to buy). The high number of visits and traffic from web shopee, may also be influenced by advertisements circulating on social media.

Social $\odot$

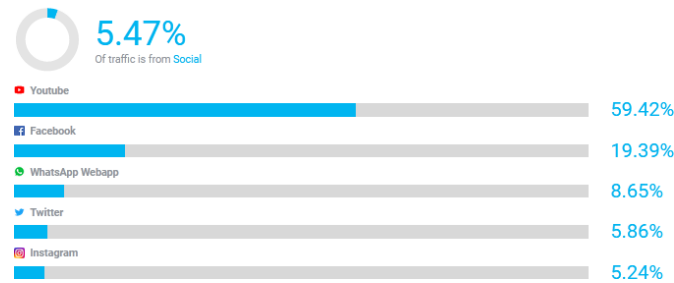

Figure3. Percentage of Shopee Ads through Social Media

Shopee not only manages advertising strategies through social media but also through Ad networkd which is dominated by ads through the Google Display Network.

\begin{tabular}{|c|c|}
\hline - Indonesia & $95.97 \%$ \\
\hline 目 United States & $\begin{array}{r}0.78 \% \\
\wedge 28.60 \%\end{array}$ \\
\hline Singapore & $\begin{array}{r}0.63 \% \\
\wedge 5.45 \%\end{array}$ \\
\hline China & $\begin{array}{r}0.49 \% \\
\sim 12.15 \%\end{array}$ \\
\hline |קa Malaysia & $\begin{array}{c}0.29 \% \\
\wedge 15.75 \%\end{array}$ \\
\hline
\end{tabular}

Figure 4.5 traffic to Shopee by Country

\section{B. Sales Promotion Shopee}

In promoting the company's brand, Shopee has a slogan in the form of "Free Postage Se-Indonesia" which is a flagship promotional program that has its own appeal for its users because in buying an item through online, consumers must increase the cost as a fare in shipping goods, so many Shopee users who try to shop at Shopee because it is considered quite profitable for consumers who like to shop online. There are many promos done by Shopee, this is seen from shopee websites that offer a variety of promos and attractive discounts. Such as cashback 8.8 mid year sale, free voucher ongking, free gift $1 \mathrm{Rp}$, flash sale, harbolnas program and also the shopee live feature, making it easier for consumers to see directly the promos offered [19]. 


\section{Brand Image Shopee}

Shopee brand names are very simple and easy in pronunciation, familiar and have different meanings. This iseasy for consumers to remember it and plant it into their minds. There will be a relationship of thought through word of mouth by consumers. Overall shopee brand names are very clear, easy to understand, and unambiguous both pronunciation and meaning. Shope logo is a very attractive orange tote bag and invites customers to shop online that can build brandequity. Slogan is the same as brand name that can build brand equity. Shopee gives the slogan Shopee has a slogan in the form of "Gratis ongkir Se-Indonesia" which is a flagship promotional program that has its own appeal for its users. Shopee has packaging that will make the factor of forming brand equity for the company, ranging from advertising, information, promotions and other small things to consider in spending online. This activity also has an impact on increasing the sales turnover of a company, because the consumer himself will be interested in seeing a product / service that is packed so beautifully [20].

\section{Characteristics of Respondents}

The object of this study was shopee company which numbered 110 respondents. The characteristics of respondents in the study are as follows.

Table 2. Characteristics of Respondents

\begin{tabular}{|c|c|c|}
\hline \multicolumn{2}{|c|}{ Sharacteristic } & Gender \\
\hline \multicolumn{3}{|c|}{ Percentage (\%) } \\
\hline Man & 32 & $29 \%$ \\
\hline Woman & 76 & $71 \%$ \\
\hline $18-25$ years old & Age & $73 \%$ \\
\hline 26 - 33 years & 23 & $22 \%$ \\
\hline $34-41$ years old & 6 & $5 \%$ \\
\hline $42-49$ years old & 0 & $0 \%$ \\
\hline \multicolumn{2}{|c|}{ Using the Shopee App } \\
\hline Yes & 110 \\
\hline No & 0 & $100 \%$ \\
\hline \multicolumn{2}{|c|}{ Frequency of Using Shopee App } \\
\hline Every day & 2 & $3 \%$ \\
\hline $1-3$ times a week & 10 & $9 \%$ \\
\hline $1-3$ times a month & 30 & $62 \%$ \\
\hline Uncertain & 68 & \\
\hline
\end{tabular}

Characteristics of respondents in table 2 The gender of the majority of respondents was women $(71 \%)$ and men $(29 \%)$. For age, dominated by the age with a range of 18 to 25 years as much as (73\%), 26 to 33 years $22 \%, 34$ to 41 years $5 \%$ of respondents. Furthermore, as many as (100\%) use the Shopee application, and for the frequency of use of shopee application in the dominance of erratic frequency with a percentage of $62 \%$, then the frequency of a month 1-3 times $26 \%$, a week $1-3$ times $9 \%$ and every day with a frequency of $3 \%$.

Based on data from previous marketers, this survey can be proven that most of Shope's visitors are women with a percentage of $71 \%$ and men $29 \%$, in addition this survey can also prove research that the main target of Shopee in addition to women also targets millennials with an age range of $18-25$ years by $73 \%$. 


\section{Descriptive Analysis}

Questionnaire is a research instrument used to determine the influence of advertising, sales promotion on buying interest in shopee companies. The questionnaire consisted of 15 valid and reliable questions. Questionnaires measured on differential semantic scales $1=$ Strongly Disagree, 2 = Disagree, $3=$ Neutral, $4=$ Agree, and $5=$ Strongly Agree .

\section{a) Distribution of Ad Variable Respondent Answers}

Ad variables are measured by 4 questions using differential semantic scale. Based on the distribution of respondents' answers, it can be known that in general the ads carried out by Shopee are quite good with an average score of 3.23. As for some items that have above average scores, namely: (1) Shopee Ads give me credible information that is useful to me with a score of 3.33 , (2) Shopee ads give me a pleasant feeling and make me forget everything for a moment with a score of 3.03 , etc. From the data can be known the highest score is contained in the information statement item from Shopee. This indicates that the company is quite good at conveying information in its advertisements.

b) Distribution of Respondent Answers Variable Sales Promotion

The sales promotion variable is measured by 4 questions using differential semantic scale. Based on the distribution of respondents' answers, it can be known that in general sales promotions conducted by Shopee are quite good with an average score of 3.50. Some items that have above average scores, Shopee often provides discounted prices offered in the application and social media with a score of 4.19 , and Shopee often provides shopping coupons on the application and on social media with a score of 3.37. From the data can be known the highest score is found on the item statement of price discount (price discount) from Shopee. This indicates that the price discount provided by the company is quite attractive to consumers..

c) Distribution of Respondent Answers Variable Brand Image

The sales brand image variable is measured by 4 questions using differential semantic scale. Based on the distribution of respondents' answers, it can be known that in general shopee brand image is quite good with an average score of 4.19. Some items that have above average scores are: (1) Shopee has functioned well in providing service to customers with a score of 4.08 , (2) Shopee has good quality in providing service to customers with a score of 4.26 . From the data can be known the highest score is found in the realibility statement item from Shopee. This indicates that the brand image of the company has high realibility.

d) Spread of Respondent Answers Variable Buy Interest

The re-buy interest variable is measured by 3 questions using differential semantic scale. Based on the distribution of respondents' answers, it can be known that in general in terms of consumer re-buying interest in shopee is good enough with an average score of 3.68. Some items that have above average scores are: (1) Shopee provides good value for customers with a score of 4.56 , (2) I consider myself to be loyal in shopping online through the Shopee app with a score of 3.06. From the data can be known the highest score contained in the item statement of value (value) about Shopee. This indicates that the company has a high value for customers.

\section{Hypothesis Testing}

Partial T-test

The calculation of the T test is carried out using the SPSS version 16 program with the following results:

Table 3 Partial TestT-test

Coefficients $^{\mathrm{a}}$

\begin{tabular}{|c|c|c|c|c|c|c|}
\hline \multirow{2}{*}{ Model } & \multicolumn{2}{|c|}{$\begin{array}{c}\text { Unstandardized } \\
\text { Coefficients }\end{array}$} & Standardized Coefficients & \multirow{2}{*}{$\mathrm{t}$} & \multirow{2}{*}{ Sig. } \\
\cline { 2 - 5 } & $\mathrm{B}$ & Std. Error & Beta & & \\
\hline 1 & (Constant) & 1.966 & .883 & & 2.226 & .028 \\
\hline
\end{tabular}

The Effect Of Advertising, Sales Promotion, And Brand Image On Repurchasing... 


\begin{tabular}{|l|l|l|l|l|l|l|}
\hline Advertisement & .140 & .068 & .195 & 2.076 & .040 \\
\cline { 2 - 6 } Sales Promotion & .177 & .065 & .238 & 2.726 & .008 \\
\hline Brand Image & .286 & .065 & .402 & 4.429 & .000 \\
\hline
\end{tabular}

a. Dependent Variable: Repurchase Intention

\section{1) Ads Variables (X1)}

The test results obtained the value $t$ for the ad variable shows the value $t=2.076 \mathrm{t}$ table of 0.1857 therefore $2.076>0.1857$ with a significance value of $0.040<0.050$. It is stated that the hypothesis is accepted. So it can be concluded that advertising has a significant influence on re-buying interests.

\section{2) Sales Promotion Variables (X2)}

The test results obtained the value $t$ for the sales promotion variable showed the value $t=$ 2.726 and the table t of 0.1857 therefore $2,726>0.1857$ with a significance value of $0.008<$ 0.050 . It is stated that hypothesis 2 is accepted. So it can be concluded that the sales promotion variable has a significant influence on re-buying interest.

\section{3) Brand Image Variables (X3)}

The test results obtained the value $t$ for the brand image shows the value of $t=4.429$ and $t$ table of 0.1857 therefore $4,429>0.1857$ with a significance value of $0.000<0.05$. It is stated that hypothesis 3 is accepted. So it can be concluded that brand image has a significant influence on buying interest using Shopee.

Based on the results of the T-test, it can be known that the variable that most affects re-interest in Shopee users is from the Brand Image variable which has the smallest significance value among other variables. This shows that Shopee's corporate brand image is a major factor that influences consumers in making repurchases on shopee app online shopping. The higher the brand image of the Shopee company, the higher the interest in consumers in the shopee company.

\section{Inter-Dimensional Correlation Test}

The correlation test in this study aims to find out the relationship of variable dimensions of advertising, sales promotion, brand image with variable repurchase intention. The results of the correlation between dimensions test in this study can be seen in the following table:

Table 4 Results of Inter-Dimensional Correlation Test

\begin{tabular}{|l|l|l|l|l|}
\hline \multirow{2}{*}{ Dimension } & Indicators & Value & Satisfaction & Quality \\
\hline \multirow{3}{*}{ Advertisement (X1) } & Information & $\mathbf{0 . 5 3 3}$ & 0.283 & 0.139 \\
\cline { 2 - 5 } & Transformation & 0.288 & 0.405 & 0.187 \\
\cline { 2 - 5 } & Emotion stimulation & 0.082 & 0.265 & 0.435 \\
\cline { 2 - 5 } & Practical Use & 0.202 & 0.158 & 0.194 \\
\hline \multirow{3}{*}{ Sales Promotion (X2) } & Discount & 0.332 & 0.421 & -0.010 \\
\cline { 2 - 5 } & Coupounds & $\mathbf{0 . 4 7 0}$ & 0.430 & 0.132 \\
\cline { 2 - 5 } & Gift & 0.288 & 0.327 & 0.192 \\
\cline { 2 - 5 } & Product Trials & 0.229 & 0.472 & 0.081 \\
\hline
\end{tabular}




\begin{tabular}{|l|l|l|l|l|}
\hline \multirow{3}{*}{ Brand Image (X3) } & Functionality & 0.550 & 0.403 & 0.322 \\
\cline { 2 - 5 } & Quality & 0.442 & 0.485 & 0.311 \\
\cline { 2 - 5 } & Realibility & 0.469 & $\mathbf{0 . 5 6 9}$ & 0.381 \\
\cline { 2 - 5 } & Fellings & 0.548 & 0.414 & 0.110 \\
\hline
\end{tabular}

\section{1) Correlation of Advertising Variables}

Based on the correlation test in table 4.11 of the correlation between dimensions that most strongly affect the buying interest of the advertising variable is the dimension of Information with a value of 0.533 which is moderately correlated. meaning that when consumers feel pleasure and also clarity of the information conveyed obtained, then buyback interest can increase through the use of shopee application while the lowest correlation between dimensions in affecting buying interest is the dimension of emotion stimulation with a value of 0.082 .

\section{2) Correlation of Variable Sales Promotion}

The correlation between dimensions that the dimensions most strongly influence re-buying interest is the coupond dimension with a value with a moderately correlated value of 0.470 . For that reason, by maintaining the provision of coupons to customers, re-buying interest will also increase. While the lowest correlation between dimensions affecting re-buying interest is the price discount dimension with quality with a value of -0.010 .

\section{3) Korelation Variable Brand Image}

Based on the results of the test the strongest correlation coefficient is in the dimension of realibility with satisfaction with a value of 0.569 which shows that the realibility or reliability of the brand image of shopee has helped influence consumers in repurchase. The lowest correlation coefficient result is in the dimension of feelings with quality with a value of 0.110 .

\section{Conclusion}

Advertising variables have a positive and significant influence on buying interest using the Shopee app, Sales promotion variables have a positive and significant influence on buying interest using the Shopee app, while Brand Image Variables have a positive and significant influence on buying interest using the Shopee app. Seway together variable advertising, sales promotion and brand image affect the interest in buying again using the shopee application.

Regression test results state that brand image variables are the variables that most affect buying interest. Based on the variables of advertising, information is the initiator that most strongly affects buying interest. Based on the variables of sales pitches, coupounds are the most powerful indicators affecting resale interest. While from the variable brand image realibility is the most powerful indicator affecting buying interest..

\section{References}

[1] T. Alam, "Cloud Computing and its role in the Information Technology," IAIC Transactions on Sustainable Digital Innovation (ITSDI), vol. 1, pp. 108-115, 2021.

[2] N. Susanti, I. Latifa, and D. Sunarsi, "The Effects of Profitability, Leverage, and Liquidity on Financial Distress on Retail Companies Listed on Indonesian Stock Exchange," Jurnal IImiah IImu Administrasi Publik, vol. 10, no. 1, pp. 45-52, 2020.

[3] F. Ishikawa and N. Yoshioka, "How do engineers perceive difficulties in engineering of machine-learning systems?-questionnaire survey," in 2019 IEEE/ACM Joint 7th International Workshop on Conducting Empirical Studies in Industry (CESI) and 6th International Workshop on Software Engineering Research and Industrial Practice (SER\&IP), 2019, pp. 2-9. 
[4] J. P. A. Ioannidis, "Meta-research: Why research on research matters," PLoS biology, vol. 16, no. 3, p. e2005468, 2018.

[5] R. D. Parashakti, M. Fahlevi, M. Ekhsan, and A. Hadinata, "The influence of work environment and competence on motivation and its impact on employee performance in health sector," in 3rd Asia Pacific International Conference of Management and Business Science (AICMBS 2019), 2020, pp. 259-267.

[6] H. Prabowo, W. Astuti, and H. Respati, "Pengaruh Service Quality dan Brand Image Terhadap Rerpurchase Intention Tamu Menginap Hotel Budget di Kota Semarang," 2020.

[7] R. A. Raji, S. Rashid, and S. Ishak, "The mediating effect of brand image on the relationships between social media advertising content, sales promotion content and behaviuoral intention," Journal of Research in Interactive Marketing, 2019.

[8] E. G. Sukoharsono, W. Bangun, and E. Setyowati, "Pacitan District Government Policy Implementation in the Sugar Coconut Industry Promotion and Development on Fta," The International Journal of Accounting and Business Society, vol. 27, no. 3, pp. 1-11, 2019.

[9] E. Dolan and A. S. Bein, "Implementation of Student Performance Management Guidance to Improve Quality Study at Colleges," IAIC Transactions on Sustainable Digital Innovation (ITSDI), vol. 1, no. 2, pp. 160-171, 2020.

[10] V. Seber, "The Effect of Interaction Via Social Media and Past Online Shopping Experience on Repurchase Intention Through Trust in Tokopedia Application Users in Surabaya," Warmadewa Management and Business Journal (WMBJ), vol. 1, no. 2, pp. 71-92, 2019.

[11] P. Priskilia and T. Sitinjak, "Pengaruh Iklan, Promosi Penjualan, Dan Persepsi Kemudahan Penggunaan Terhadap Minat Memakai Ulang Layanan Go-Pay Di Wilayah Jakarta," Jurnal Manajemen, vol. 9, no. 1, 2019.

[12] G. N. M. Nata, S. Anthony, and P. P. Yudiastra, "Knowledge Discovery And Virtual Tour To Support Tourism Promotion," IAIC Transactions on Sustainable Digital Innovation (ITSDI), vol. 2, no. 2, pp. 94-106, 2021.

[13] S. M. T. Pandiangan, I. N. Resmawa, O. D. P. Simanjuntak, P. N. Sitompul, and R. Jefri, "Effect of E-Satisfaction on Repurchase Intention in Shopee User Students," Budapest International Research and Critics Institute (BIRCI-Journal): Humanities and Social Sciences, vol. 4, no. 4, pp. 7785-7791, 2021.

[14] I. Soleha, R. Arifin, and A. Rahmad, "Pengaruh Citra Merek Dan Persepsi Label Halal Terhadap Minat Pembelian Ulang Produk Kosmetik Zoya Malang," e - Jurnal Riset ManajemenPRODI MANAJEMEN Fakultas, vol. 000, no. 2, pp. 166-176, 2017.

[15] N. Sari and I. Santika, "Pengaruh Brand Image, Brand Association, Dan Brand Awareness Terhadap Repurchase Intention Produk Smartphone Merek Asus," EJurnal Manajemen Universitas Udayana, vol. 6, no. 8, p. 254093, 2017.

[16] M. A. Shareef, B. Mukerji, Y. K. Dwivedi, N. P. Rana, and R. Islam, "Social media marketing: Comparative effect of advertisement sources," Journal of Retailing and Consumer Services, vol. 46, pp. 58-69, 2019.

[17] H. H. Abdullah, J. R. M. Hanaysha, and N. H. Abd Ghani, "Analyzing the relationship between advertising and sales promotion with brand equity," Asian International Journal of Social Sciences, vol. 17, no. 2, pp. 88-103, 2017.

[18] N. Adiyanto, "Customer Relationship Management (CRM) Based On Web To Improve The Performance Of The Company," IAIC Transactions on Sustainable Digital Innovation (ITSDI) The 1st Edition Vol. 1 No. 1 October 2019, p. 32, 2021.

[19] Y. C. Gu, "The Influence of Sales Promotion, Perceived Product Quality and Hedonic Perception on Consumers' Purchase Intention-The Moderating Effect of Brand Awareness." UTAR, 2019.

[20] H. A. Mabkhot, H. Shaari, and S. M. Salleh, "The influence of brand image and brand personality on brand loyalty, mediating by brand trust: An empirical study," Jurnal Pengurusan (UKM Journal of Management), vol. 50, 2017. 